\title{
INCONSISTENCIES OF FOOT TYPE CLASSIFICATION
}

\author{
Raminta Sakalauskaitė', Danguolė Satkunskiené $\dot{1}^{1,2}$ \\ Lithuanian Academy of Physical Education', Kaunas, Lithuania \\ Kaunas University of Technology², Kaunas, Lithuania
}

\begin{abstract}
Research background and hypothesis. Literature analysis shows that researchers try to determine which method used for foot type estimation is the most reliable, and look for correlations between directly received foot measurements (indexes, angles) ignoring assessment scales. Given different medial longitudinal arch (MLA) assessment scales, the comparison, discussion and conclusions of the obtained data might be unreliable.

Research aim of this study was to determine the reliability of foot type classification: a) to assess correlation links between results from various methods used to analyse foot; b) to identify foot type distribution according to medial longitudinal arch.

Research methods. The MLA of 182 feet was assessed using four prevalent foot type evaluation methods: the Chipaux-Smirak Index (CSI), the Staheli Index (SI), the Clarke angle (CLA) and arch index by D. S. Williams (WAI). Pearson's correlation was used to determine links between foot indexes.

Research results. Very strong link was found between CSI and SI footprint indexes, while medium negative correlation was determined between Clarke angle with Chipaux-Smirak (CSI) and Staheli (SI) indexes. Average amount of low arch foot assessed according to the foot type classification scales by the four methods was 64.0 $(\mathrm{SD}=65.5)$, normal foot $92.25(\mathrm{SD}=51.77)$ and high arch foot $25.75(\mathrm{SD}=35.33)$.

Discussion and conclusion. Research showed that current foot arch classification was not reliable. The foot type classification scales presented by F. Forriol, L. T. Staheli, N. M. Clarke and D. S. Williams define different medial longitudinal foot arch distribution by testing the same pairs of feet despite the correlative link intensity between foot arch indexes.
\end{abstract}

Keywords: footprint, foot arch, assessment scale.

\section{INTRODUCTION}

$\mathrm{M}$ any methods are currently being used to classify the medial longitudinal foot arch (MLA). Literature review shows that no general consensus exists on the best method for foot type classification. Existing methods are typically based on the measurement of morphological parameters of the foot, mostly in the standing weight-bearing position, or during locomotion (Razeghi, Batt, 2002). Direct methods for MLA height assessment include taking radiographs, which provide a reliable method for evaluating the structure of the foot during weight bearing (Villarroya et al., 2009). Many research laboratories do not have access to such methods, therefore indirect methods that are used include footprint analysis, which is still the most popular method to analyse and assess the MLA (Cavanagh, Rodgers, 1987; Staheli et al., 1987; Forriol, Pascual, 1990; McCroy et al., 1997). However, controversial findings are published in literature. Some authors have reported that footprints are not good indicators for determining foot type (Hawes et al., 1992; Saltzman et al., 1995), whereas others consider that it is a reliable technique (Cavanagh, Rodgers, 1987; Staheli et al., 1987; Forriol, Pascual, 1990; McCroy et al., 1997).

Literature analysis shows that researchers trying to determine which method used for 
foot type estimation is the most reliable, are looking for correlation between directly received foot measurements (indexes, angles) ignoring assessment scales that classify foot arch into three stages according to specific indications (normal, high and low arch). In our opinion, even if some of foot indexes correlate when applying various foot type classification methods, the results might be diverse. However, despite the method used the determined foot arch type must be the same.

The aim of this research was to determine the reliability of foot type classification: a) to assess correlation links between results from various methods used to analyse foot; b) to identify foot type distribution according to medial longitudinal arch.

\section{RESEARCH METHODS}

In our research, 182 feet of 91 subjects (44 female and 47 male) were measured to establish a mean and standard deviation for a reference population. The average age of subjects was $23.9 \pm 5.1$ years with an average weight of $74.5 \pm$ $11.5 \mathrm{~kg}$. All subjects who took part in this study were volunteers from a university population and the surrounding community. None of the subjects had lower-extremity abnormalities or injuries at the time of measurement. Subjects were informed about the course of the research. The National Bioethics Committee reviewed and approved the study protocol.

MLA was assessed using four prevalent foot type evaluation methods: the Chipaux-Smirak Index (CSI), the Staheli Index (SI), the Clarke angle (CLA) and arch index by Williams (WAI).

Foot measurements were taken using footprints and video recording. The footprints were used to estimate the foot arch using three methods (CSI, SI, CLA) and filming was used for the Williams method (AI).

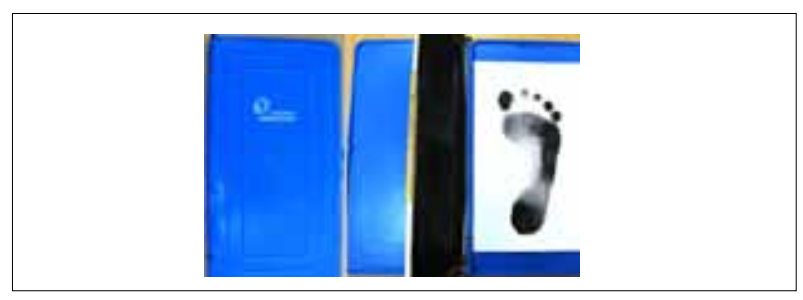

Figure 1. A Globus Berkemann plate

Static footprints were taken from a standing position on a Globus Berkemann plate, one leg in a weight-bearing position. For the analysis of the CSI, SI and CLA, necessary lines were drawn with a pencil and two rulers on the footprints following the authors' instructions (Clarke, 1933; Staheli et al., 1987; Forriol, Pascual, 1990).

The Chipaux-Smirak Index (CSI) is the ratio between minimal width of the medial longitudinal arch area (b) and maximal width of the metatarsal print (a). (b) is parallel to (a). CSI $=$ b/a. Five categories are described for the MLA classification according to CSI- $0 \%$ - foot with elevated arch; $0.1-29.9 \%$ - foot with a morphological normal arch; 30-39.9\% - intermediate foot; $40-44.9 \%$ foot with a lowered arch; $45 \%$ or higher - flatfoot (Forriol, Pascual, 1990).

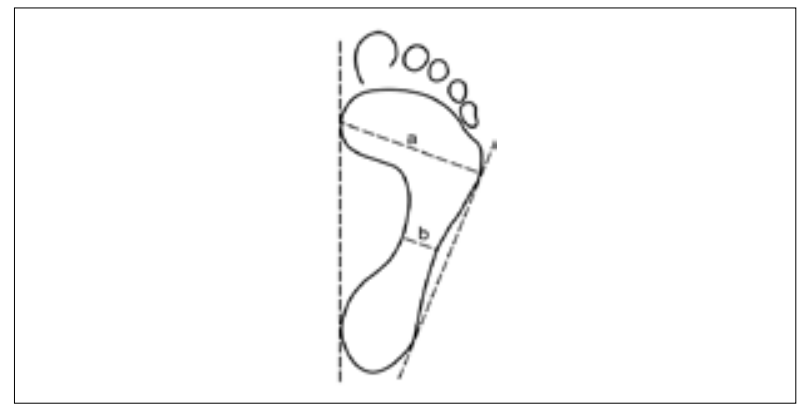

Figure 2. The Chipaux-Smirak Index (Onodera et al., 2008)

The Staheli Index (SI) is the ratio between minimal width of the medial longitudinal arch area (b) and maximal width of the heel print (c). (c) is parallel to (b). SI $=b / c$. The MLA is classified as follows: $\leq 0.43$ - high arch; $0.44-0.89$ - normal; $\geq 0.90$ - low (Staheli, 1997).

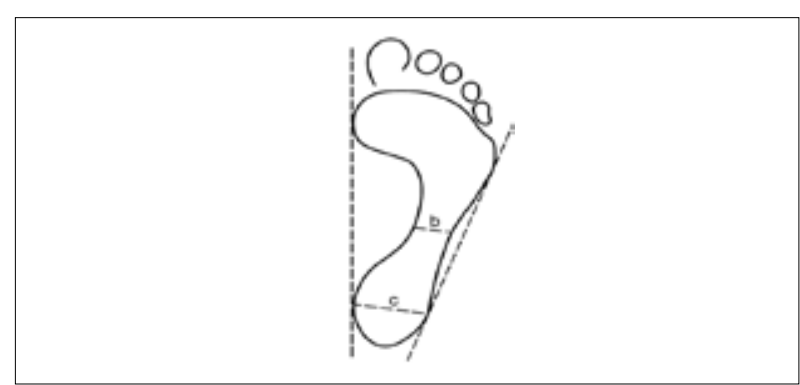

Figure 3. The Staheli Index (Onodera et al., 2008)

For calculation of the Clarke's angle (CLA) the line "AC" was drawn between point $\mathrm{A}$ and the apex of the concavity of the arch of the footprint (point $\mathrm{C}$ ). The CLA is the angle between lines "AB" and "AC". The MLA is classified as follows: $55^{\circ}$ is overarched; $42-54^{\circ}$ normal MLA; $31-41^{\circ}$ flattened; $30^{\circ}$ and below is flatfoot (Clarke, 1933). 


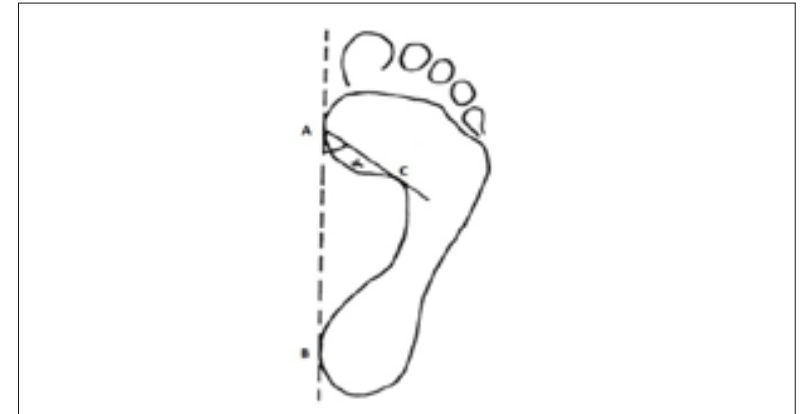

Figure 4. The Clarke's angle (Onodera et al., 2008)

Arch index by D. S. Williams (WAI) is dorsum height (DORS) divided by arch length (AL). Dorsum height was measured from the floor to the top of the foot at $50 \%$ of foot length. Foot length (FL) was measured from the most posterior portion of the calcaneus to the end of the longest toe. Arch length was measured from the most posterior portion of the calcaneus to the center of the first metatarsophalangeal joint. For Williams method, arch height was measured with the digital photographic method (Pohl, Farr, 2010). The MLA is classified as follows: ${ }^{3} 0.357$ - high arch; 0.3560.275 - normal and $\leq 0.274$ is low MLA (Williams, Mc Clay., 2000).

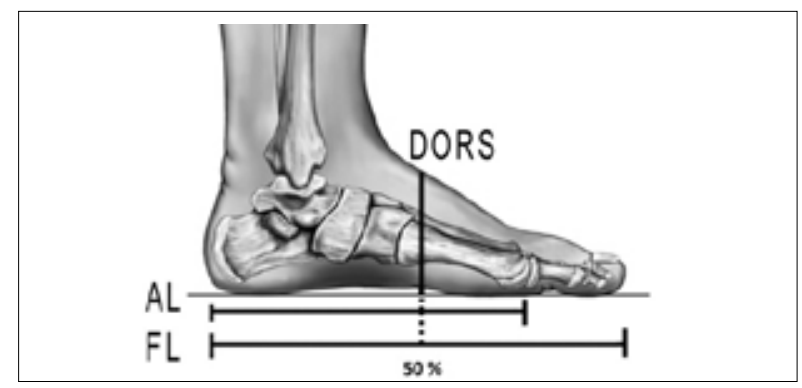

Figure 5. The Arch Index by D. S. Williams

The sagittal plane of foot placed in a weightbearing position was filmed with a digital video camcorder Canon XM-1. Before filming four markers were attached to the skin in the following landmarks on the legs of each subject: 1) head of the first metatarsal, 2) dorsum midpoint between the most posterior portion of the calcaneus to the end of the longest toe, 3) most posterior portion of the calcaneus, 4) the end of the longest toe.
The fixed markers were manually digitized using the software SIMI Motion. Foot length and dorsum height were analysed from the side view. To check the accuracy of the systems used, an error analysis of point marking, repeated digitizing, and foot dorsum height and foot length measurements were conducted. The standard error of the relative mean difference was also calculated (1.1\%).

All calculated indexes were tested for normality of distribution using SPSS 14 packet and the Kolmogorov-Smirnov test.

Aiming at comparing the classifications presented by different authors, the uniform assessment scale was used: 1 - low MLA, 2 normal MLA, 3 - high MLA. The low, lowered and intermediate arch heights were designated to group 1. The elevated and high arch types were appointed to group 3 (Onodera et al., 2008). The number of low, normal and high MLA was calculated according to all scales mentioned above. Pearson's correlation was used to determine links between foot indexes. The significance level was $p<0.01$. Mean and standard deviations of quantity of low, normal and high arch foot were calculated.

\section{RESEARCH RESULTS}

The foot arch indexes calculated by each selected methods were tested for normality of distribution. Probability plots (Q-Q plots; "Q" stands for quantile) of each variable are presented in Figure 6. Q-Q plots show that all foot arch indexes fit theoretical normal distribution. Only Clarke's angle does not match the test distribution (Kolmogorov-Smirnov test: $\mathrm{p}<0.05$ ).

Table shows strong link between CSI and SI footprint indexes, while medium negative correlation was determined between Clarke angle with Chipaux-Smirak (CSI) and Staheli (SI) indexes.

Distribution of foot measurements according to different methods used is provided in Figure 7. Average amount of low arch foot assessed according to the foot type classification scales by the four authors was 64.0 ( $\mathrm{SD}=65.5)$, normal foot 92.25 $(\mathrm{SD}=51.77)$ and high arch foot $25.75(\mathrm{SD}=35.33)$.

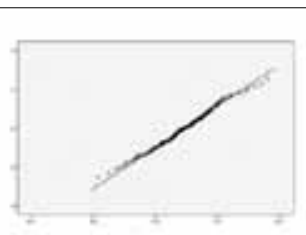

WAI

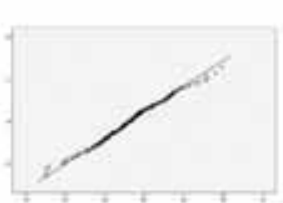

CSI

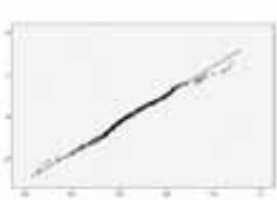

SI

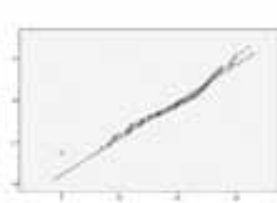

CLA
Figure 6. Distribution of Q-Q Plots of Williams, CSI, SI indexes and Clarke's angle

Note. The arch index by Williams (WAI), the Chipaux-Smirak Index (CSI), the Staheli Index (SI), the Clarke angle (CLA). 
Note. The arch index by Williams (WAI), the Chipaux-Smirak Index (CSI), the Staheli Index (SI), the Clarke angle (CLA). * - Correlation is significant at the 0.01 level (2-tailed).

\begin{tabular}{|c|c|c|c|c|c|}
\hline \multirow{2}{*}{ WAI } & WAI & CSI & SI & CLA \\
\hline & Pearson's Correlation & 1 & & & \\
\hline \multirow{2}{*}{ CSI } & Sig. (2-tailed) & & & & \\
\hline \multirow{2}{*}{ SI } & Pearson's Correlation & $-0.311^{*}$ & 1 & & \\
\cline { 2 - 6 } & Sig. (2-tailed) & 0.000 & & & \\
\hline \multirow{2}{*}{ CLA } & Pearson's Correlation & $-0.326^{*}$ & $0.901^{*}$ & 1 & \\
\cline { 2 - 6 } & Sig. (2-tailed) & 0.000 & 0.000 & & \\
\cline { 2 - 6 } & Pearson's Correlation & 0.152 & $-0.622^{*}$ & $-0.599^{*}$ & 1 \\
\hline
\end{tabular}

Figure 7. Feet distribution by the different methods

Note. The arch index by Williams (WAI), the Chipaux-Smirak Index (CSI), the Staheli Index (SI), the Clarke angle (CLA).

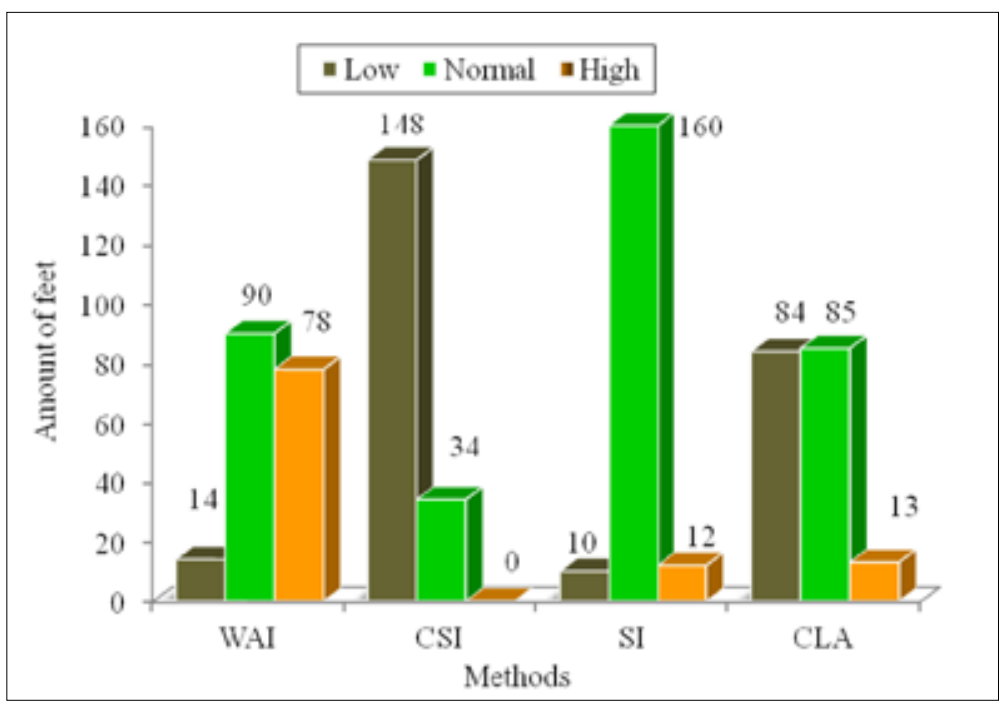

\section{DISCUSSION}

There are several methods to evaluate medial longitudinal foot arch, therefore researchers, as well as practitioners (orthopedists, physiotherapists), often raise the question which one of the methods should be used. Which one is the most reliable? Which one is the most accurate? Do the results of medial longitudinal arch evaluation differ depending on the method used?

It is considered that the most accurate method is to use X-rays, when usually two angles of the foot evaluating foot arch are measured: between the first metatarsal and the calcaneus inclination (Saltzman et al., 1995). Aiming at determining the reliability of footprint measurements, researchers look for correlative links between footprint and rentgenography indexes. U. Kanatli (2001) alongside with other scientists identified a medium correlative link between Staheli arch index (SI) and foot lateral talo-first metatarsal angle rentgenogram. A. M. Onodera et al. (2008) analysed children's feet at various ages and calculated the arch indexes of Cavanagh and Rodgers (AI), Chipaux-Smirak (CSI), Staheli (SI) and the Alpha (or Clarke) Angle (AA). The indices showed clear and significant correlations between each other ( $\mathrm{R}$ above 0.75 , $\mathrm{p}<0.001)$ except for SI and AA with AI. In this research correlation method was applied in order to determine statistical link between different indexes evaluating foot arch provided by various measurement methods. The research showed that the most correlative indexes were the ones from footprint: there was a strong link between CSI and SI and a medium correlative link between Clarke angle and Chipaux-Smirak (CSI) and Staheli (SI) index.

The D. S. Williams method (2000) is based on the ratio of foot height and length; its reliability was tested by C. L. Saltzman et al. (1995) using the rentgenographic method. C. L. Saltzman et al. (1995) determined a strong correlative link between the ratio of foot arch height and length (h/l) and foot arch X-ray measurements. The correlative ratio between D. S. Williams' method and footprint measurements that we calculated in our research showed a weak link between the markers used to determine foot arch height. A. N. Onodera et al. (2008) conducted research where feet were evaluated according to different scales provided by various research methods. Having compared the number of high, low and normal feet (numbers where 
obtained using different methods to compare the same feet) they discovered a statistically significant difference between Staheli (SI) and ChipauxSmirak (CSI) footprint evaluation methods: out of 782 feet assessed to the CSI method normal feet constituted $52.9 \%$, high $-4.3 \%$, and low $42.9 \%$, and according to the SI method normal feet arches constituted $74.3 \%$, high arches $-20 \%$ and low feet arches $-5.7 \%$. The results obtained using CSI and SI methods in our research were also different. According to the CSI method, low arch feet were dominant and constituted $18.7 \%$, whereas high arch feet were absent. Meanwhile the SI method showed that the dominant arch type was normal $(87.9 \%)$, low arch feet constituted $5.5 \%$ and high arch $-6.6 \%$. The results of our research based on SI method had a similar distribution with A. N. Onodera et al. (2008) analysis.

The results of Clarke and Williams methods were rather similar, as the number of feet with normal arch found using both methods were close (according to Clarke method, feet with normal arch constituted $46.7 \%$ and according to Williams method $-49.5 \%$ ). However, the number of low and high arch feet were different. Based on Clarke method, low arch feet constituted 46.2\%, high arch-7.1\%; whereas according to Williams method, the results where $7.7 \%$ and $42.8 \%$ accordingly. Having evaluated the distribution of feet obtained using all methods we can propose that the foot type classification scales presented by F. Forriol, L. T. Staheli, N. M. Clarke and D. S. Williams define different MLA distribution by testing the same pairs of feet.

Why was the distribution of foot arch type so diverse using each analysis method and did not correspond to normal distribution law, although all, except H. H. Clarke's angle, foot arch indexes calculated by each selected methods were tested for normality of distribution using KolmogorovSmirnov test? Analysis of foot evaluation scales, provided by the authors, has shown that they were composed differently. For example, according to the evaluation scale by Staheli, foot is considered to be normal when the impression indexes distribute between \pm 2 SD from average. According to Chipaux-Smirak, the normal index is \pm 1 SD from average, and according to Williams it is \pm 1.5 SD. Unfortunately, authors did not indicate what their scales were based on. We believe that not the indexes describing medial longitudinal arch but the evaluation scales could have had the influence on such a diverse number of foot with high, normal and low arch.

A. N. Onodera's (2008) children foot arch research conducted using several methods showed that the highest number of normal arch feet was received using SI method. Author argued that it was the result of criteria differences established by each author when classifying MLA.

Since there are no parameters of a normal foot structure and function, the establishment of the foot type have to be based on mathematical statistics using probability density function of the normal distribution. According to the normal distribution, the first quartile (that suffice low foot arch) cut off the lowest $25 \%$ of data, the second quartile (normal foot arch) cut data set in half (50\% of data), and third quartile (high foot arch) cut off the highest $25 \%$ of data. Our opinion is that if evaluation scales are constituted according to normal distribution of quartile, the number of feet measured using different methods should conform.

\section{CONCLUSIONS AND PERSPECTIVES}

Research showed that current foot arch classification was not reliable. The foot type classification scales presented by F. Forriol, L. T. Staheli, N. M. Clarke and D. S. Williams define different medial longitudinal foot arch distribution by testing the same pairs of feet despite the correlative links intensity between foot arch indexes.

\section{REFERENCES}

Cavanagh, P. R., Rodgers, M. M. (1987). The arch index: A useful measure from footprints. Journal of Biomechanics, 20, 547-551.

Clarke, H. H. (1933). An objective method of measuring the height of the longitudinal arch in foot examinations. Research Quarterly, 4, 99-107.

Forriol, F., Pascual, J. (1990). Footprint analysis between three and seventeen years of age. Foot Ankle, 11 (2), 101-104.
Hawes, M. R., Nachbauer, W., Sovak, D., Nigg, B. M. (1992). Footprints parameters as a measure of arch height. Foot Ankle, 13 (1), 22-26.

Kanatli, U., Yetkin, H., Cila, E. (2001). Footprint and radiographic analysis of the feet. Journal of Pediatric Orthopaedics, 21 (2), 225-228.

McCroy, J. L., Young, M. J., Boulton, A. J., Cavanagn, P. R. (1997). Arch index as a predictor of arch height. Foot, 7 (2), 79-81. 
Onodera, A. N., Sacco, I. C., Morioka, E. H. et al. (2008). What is the best method for child longitudinal plantar arch assessment and when does arch maturation occur? Foot, 18 (3), 142-149.

Pohl, M. B., Farr, L. (2010). A comparison of foot arch measurement reliability using both Digital photography and calliper methods. Journal of Foot and Ankle Research, 3, 14.

Razeghi, M., Batt, M. E. (2002). Foot type classification: A critical review of current methods. Gait \& Posture, 15 (3), 282-291.

Saltzman, C. L., Nawoczenski, D. A., Talbot, K. D. (1995). Measurement of the medial longitudinal arch.
Archives of Physical Medicine and Rehabilitation, 76 (1), 45-49.

Staheli, L. T., Chew, D. E., Corbett, M. (1987). The longitudinal arch. A survey of eight hundred and eightytwo feet in normal children and adults. The Journal of Bone and Joint Surgery, 69 (3), 426-428.

Villarroya, M. A., Esquivel, J. M., Tomás, C. et al. (2009). Assessment of the medial longitudinal arch in children and adolescents with obesity: Footprints and radiographic study. European Journal of Pediatrics, 168 (5), 559-567.

Williams, D. S., McClay, I. S. (2000). Measurements used to characterize the foot and medial longitudinal arch: Reliability and validity. Physical Therapy, 80 (9), 864-871.

\title{
PE்DOS TIPO KLASIFIKAVIMO NESUDERINAMUMAS
}

\author{
Raminta Sakalauskaitė ${ }^{1}$, Danguolè Satkunskienè $\dot{e}^{1,2}$ \\ Lietuvos kūno kultūros akademija ${ }^{1}$, Kaunas, Lietuva \\ Kauno technologijos universitetas ${ }^{2}$, Kaunas, Lietuva
}

\section{SANTRAUKA}

Tyrimo pagrindimas ir hipotezè. Analizuojant literatūrą pastebèta, kad mokslininkai, norèdami nustatyti, kuris pèdos vertinimo metodas yra patikimiausias nusakant pèdos skliauto tipa, ieško koreliacijos ryšiu tarp tiesiogiai išmatuotų ar paskaičiuotų pẻdos rodiklių (indeksų, kampų), neatsižvelgdami i vertinimo skales. Turint skirtingas pẻdos skliauto vertinimo skales, gautų duomenų išvados ir interpretacijos gali būti nepatikimos.

Tikslas - nustatyti pėdos tipo klasifikavimo patikimumą: a) ivertinti koreliacijos ryši tarp pėdos rodiklių, tirtu skirtingais metodais; $b$ ) nustatyti pèdų pasiskirstymą pagal išilginio skliauto tipa.

Metodai. 182 pedu vidinis išilginis skliautas buvo vertintas keturiais metodais: skaičiuojamas Chipaux-Smirak indeksas (CSI), Staheli indeksas (SI), Clarke kampas (CLA) ir skliauto indeksas pagal D. S. Williams (WAI). Tarp indeksu ir kampo buvo skaičiuotas Pirsono koreliacijos koeficientas.

Rezultatai. Labai stiprus koreliacijos ryšys aptiktas tarp CSI ir SI pèdos antspaudo indeksų, o vidutinis neigiamas ryšys buvo tarp Clarke kampo ir Chipaux-Smirak (CSI) bei Staheli (SI) indekso. Ivertinus pèdos skliautą keturiais metodais paaiškejjo, kad žemo skliauto pèdų vidutiniškai buvo $64,0 \pm 65,5$, normalių pẻdu $-92,25 \pm 51,77$ ir aukšto skliauto pèdu - vidutiniškai $25,75 \pm 35,33$.

Aptarimas ir išvados. Atlikus tyrimą nustatyta, kad pedos skliauto klasifikavimas yra nepatikimas. Nors koreliacijos ryšys tarp skirtingų metodų rodiklių buvo stiprus, pèdų pasiskirstymas pagal išilgini pėdos skliauto tipą buvo nevienodas.

Raktažodžiai: pėdos antspaudas, pèdos skliautas, vertinimo skalè.

\author{
Corresponding author Raminta Sakalauskaitė \\ Lithuanian Academy of Physical Education \\ Sporto str. 6, LT-44221 Kaunas \\ Lithuania \\ Tel +370-37 209144 \\ E-mail r.sakalauskaite@lkka.1t
}

